Original Research Article

\title{
Calcium and Osteoporosis: An Important Mineral for Women
}

Pareek, Surbhi

Santokba Durlabhji Memorial Hospital cum Medical Research Centre, Jaipur, Rajasthan

Corresponding Author: surbhi.pareek91@gmail.com

\section{A R T I C L E I N F O}

Received: 11 January 2018 | Accepted: 22 April 2018 | Published Online: 15 August 2018

DOI: $10.31786 / 09756272.18 .9 .1 .121$

EOI: $10.11208 /$ essence.18.9.1.121

Article is an Open Access Publication.

This work is licensed under Attribution-Non Commercial 4.0 International

(https://creativecommons.org/licenses/by/4.0/)

CThe Authors (2018). Publishing Rights @ MANU_ICMANU \& ESSENCE-IJERC.

\section{A B S T R A C T}

In today's date, Osteoporosis is a growing health problem in many countries around the world. It is one of the most common complaints in people aged 50 and over and affecting around 30\% of women and $8 \%$ of men in this age group. Women are more exposed to osteoporosis and osteoporotic fractures then men.

\section{K E Y W O R D S}

Women health | Osteoporosis | Calcium mineral | Bone Fractures | Calcium Food

\section{I T A T I O N}

Pareek, Surbhi (2018): Calcium and Osteoporosis: An Important Mineral for Women. ESSENCE Int. J. Env. Rehab. Conserv. IX (1): 45-53. 


\section{Introduction}

In today's date, Osteoporosis is a growing health problem in many countries around the world (Kaptoge et al., 2008). It is one of the most common complaints in people aged 50 and over and affecting around $30 \%$ of women and $8 \%$ of men in this age group (Czerwiński et al., 2011) Women are more exposed to osteoporosis and osteoporotic fractures then men (Badurski et al., 2007 and Hooven et al., .2009).

The Importance of Calcium for Women For women, the main important function of calcium is bone development. Major part (around 99 percent) of the calcium in the human body is found in the bones and teeth; it is essential for the proper development, growth, and maintenance of bone. It continues strengthening the bones of humans until they reach the age of 20-25 when bone density is highest. After the age of 25, bone density declines, but calcium continues to help maintain bones and slow down bone density loss, which is a natural part of the aging process. Calcium gives strength to the bones and makes them strong. Apart from that It is also necessary for lots of other body's functions, such as blood clotting and nerve function and muscle contraction. During the teenage years (particularly in ages 11-15), the bones are developing rapidly and are storing calcium so that the skeleton will be strong later in life. Nearly half of all bone is formed during these years. It's very important to have plenty of calcium in the diet because if the rest of the body doesn't get the calcium it needs, it takes out calcium from the only source that it has: the bones. This can lead to brittle bones later years in life and broken bones or stress fractures at any time.

Women who do not consume enough calcium before the age of 20-25 have a considerably higher risk of developing brittle bone disease or osteoporosis later in life; this is because calcium is drawn from the bones as a reserve. Adolescent girls actually do not consume enough calcium in their diet.

Along with the calcium, Vitamin D also plays an important role in bone health because it helps in absorption of calcium in the body and makes bone strong (Newsletter on Vitamin D 2014).

\section{What is osteoporosis?}

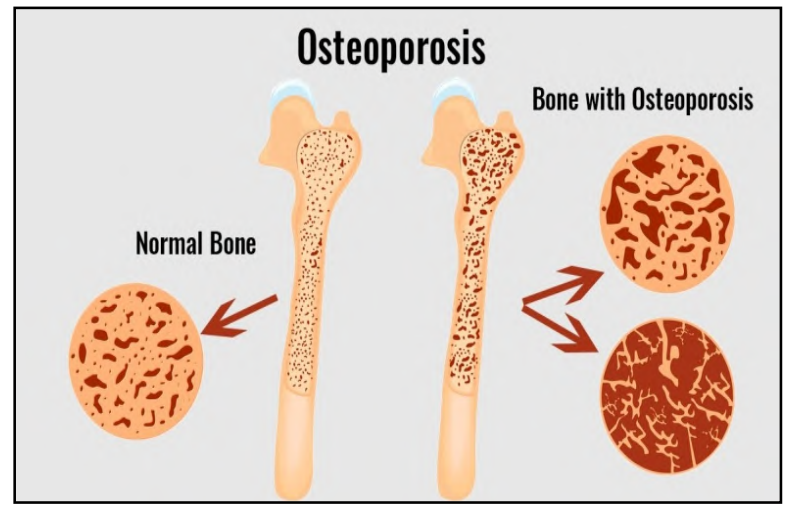

Osteoporosis is a bone disease that causes bones to become brittle and fragile and more likely to break. It develops slowly and is usually caused by a combination of genetics and too.

Because of Lack of calcium in the diet, Osteoporosis can also lead to shortened height because of collapsing spinal bones and can cause a hunched back

Various factors can put a young person at risk for developing osteoporosis. These include:

- Being white

- Being female

- Being underweight

- Body weight and bone structure

- Certain diseases like rheumatoid arthritis

- Some medications

- Having a family history of osteoporosis

- Having irregular periods

- Doing little or no exercise

- Not getting enough calcium in your diet

- Smoking

- Drinking large amounts of alcohol

\section{How much calcium do you need?}

According to Indian council of medical research (ICMR), Children and teenagers between the ages of 9 and 18 should aim for 600-1000 milligrams per day, which are about 4 servings of calcium rich foods and drinks. One glass of milk (whether skim, $1 \%, 2 \%$, or whole) and each cup of yogurt has about 300 milligrams of calcium. Adults 19 to 50 years of age should aim for 1,000 milligrams 
per day. For women, requirements of calcium get increases during the period of pregnancy and lactation (Gopalan et al., 2007)

So, teenage girls and Young women need to make sure they get enough calcium, as they can achieve their peak bone mass just after this age.

Having adequate amount of calcium will help her bones reach optimum bone density. This can help protect her from osteoporosis later in life.

Mature women need calcium to prevent break down of bone. There is also a growing body of research that suggests that calcium may prevent PMS.

Researchers have proven that Consumption of dairy products in childhood and adolescence may improve bone mineral density and reduce the risk of osteoporosis in adult women (Lidia et al., 2013)

\section{Where is the calcium?}

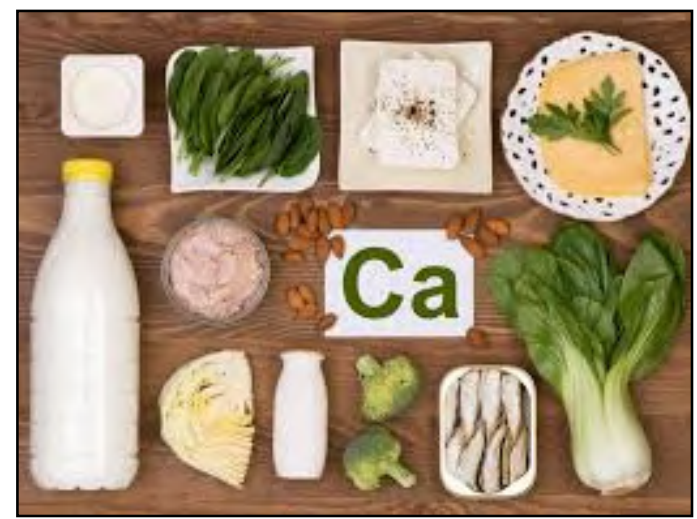

When we talk about calcium, we think that we can get calcium from milk and its products only but here are lots of foods in our diet which contains good amount of calcium. These are:

1) Milk (whole, $2 \%, 1 \%$, and skim) contains 315 $\mathrm{mg} / \mathrm{cup}$ and yogurt contains $259 \mathrm{mg}$ per $3 / 4$ cup.

2) Non-dairy foods: broccoli $(36 \mathrm{mg} / 0.5 \mathrm{cup}$ cooked), sardines (420 mg/213 g), clams, oysters, turnip greens ( $99 \mathrm{mg} / 0.5$ cup cooked), and mustard greens.

3) Artificially calcium-fortified: juices and cereals. Calcium-fortified orange juice contains $320 \mathrm{mg} / \mathrm{cup}$, while calcium-fortified cereals contain $200 \mathrm{mg} / \mathrm{cup}$.
4) Jow, Niger seeds, beans also re good source of calcium.

5) Other forms: Soy milk (200-500 mg/cup), soy nuggets, soy granules, tofu.

6) Supplements: calcium carbonate, calcium citrate, calcium gluconate, calcium glubionate, calcium lactate, tricalcium phosphate.

Don't Forget About Vitamin D: Vitamin D is very important in moving calcium to your bones.

What you have to Eat?

Early morning: A cup of Green tea with soaked almonds and walnuts

Breakfast: A glass of skimmed milk with veg poha / veg daliya / oats daliya / veg upma /stuffed chapatti 1 / veg sandwich with brown bread ( 2 pieces) / idli with sambhar

Mid morning: any seasonal fruit with a glass of buttermilk or calcium fortified juices

Lunch: A full plate of green salad with chapatti, curd and green vegetable with a bangali dessert

Evening tea: A cup of tea with sprout lemon chat with paneer or paneer tikka or paneer cutlets

Dinner: A bowl of thick soup with chapatti, dal and green vegetable

Bedtime: a serving of milk ( Milk, rasgulla, custard)

\section{What if you're lactose intolerant?}

If you are lactose intolerant and can't drink milk, there are plenty of other foods to get enough calcium. You can consume other forms of milk like curd, cheese, paneer as the form of lactose present in milk gets convert in to lactic acid in curds and other products. Apart from that you can also consume soy milk, tofu, almond milk, coconut milk etc. Now a day's lots of products are available in market which are fortified with calcium like fortified juices, soy milk etc.

\section{References:}

Badurski, J. E.; Czerwiński, E.; MarcinkowskaSuchowierska E. Zalecenia Polskiej Fundacji Osteoporozy i Polskiego Towarzystwa Osteoartrologii wobec osteoporozy w oparciu o stanowisko Światowej Organizacji Zdrowia (WHO) i Międzynarodowej Fundacji Osteoporozy (IOF) Ortop. Traumatol. Reha- 
Czerwiński, E.; Osieleniec, J. and Borowy, P. (2011): Osteoporoza-Choroba Milionów ZBamań. Fakty. [(accessed on 20 October 2011)]. Available online: http:// w w w . o s t e o p o r o z a . p 1/ attachments/1617_Osteoporoza-fakty_201110-18kb.pdf.

Gopalan, C.; Ramashastri, B. V. and Balasubramanian, S. C. (2007): Nutritive value of Indian foods. Hyderabad, Andhra Pradesh: National institute of nutrition.

Hooven F., Adachi J., Adami S., Boonen S., Compston J., Cooper C., Delmas P., DiezPerez A., Gehlbach S., Greenspan S., et al. The Global Longitudinal Study of Osteoporosis in Women (GLOW): Rationale and study design. Osteoporos. Int. 2009; 20:1107-1116. doi: 10.1007/s00198-009-0958-2.

Kaptoge, S.; Da, Silva J.; Brixen, K.; Reid, D.; Kroger, H.; Nielsen, T.; Andersen, M.; Hagen, C.; Lorenc R. and Boonen, S. (2008): Geographical variation in DXA bone mineral density in young European men and women. Results from the Network in Europe on male osteoporosis (NEMO) study. Bone. 43:332339.

Lidia, W.; Kamila, S.; Justyna, W.; Malgorzata, A.; Magdalena, C. and Ewa, N. (2013): Dairy Products, Dietary Calcium and Bone Health: Possibility of Prevention of Osteoporosis in Women: The Polish Experience; Nutrients, 5, 2684-2707; doi:10.3390/nu5072684

News shelter (2014): Vitamin D: An important nutrient that protects you against falls and fractures. Osteoporosis. Senior Science, Canada. 